\title{
Social and Cultural Influences on Management for Carbon Sequestration on US Family Forestlands: A Literature Synthesis
}

\author{
A. Paige Fischer ${ }^{1}$ and Susan Charnley ${ }^{2}$ \\ ${ }^{1}$ USDA Forest Service, Pacific Northwest Research Station, 3200 SW Jefferson Way, Corvallis, OR 97331, USA \\ ${ }^{2}$ USDA Forest Service, Pacific Northwest Research Station, 620 SW Main St., Suite 400, Portland OR 97205, USA
}

Correspondence should be addressed to A. Paige Fischer, paigefischer@fs.fed.us

Received 10 April 2010; Revised 6 November 2010; Accepted 21 December 2010

Academic Editor: Jeffrey Kline

Copyright ( 2010 A. P. Fischer and S. Charnley. This is an open access article distributed under the Creative Commons Attribution License, which permits unrestricted use, distribution, and reproduction in any medium, provided the original work is properly cited.

\begin{abstract}
Nonindustrial private_or "family" — forests hold great potential for sequestering carbon and have received much attention in discussions about forestry-based climate change mitigation. However, little is known about social and cultural influences on owners' willingness to manage for carbon and respond to policies designed to encourage carbon-oriented management. We review the published literature to examine how family forest owners' values, ecological knowledge, risk perceptions, and forest management and policy preferences may affect their interest in managing for carbon sequestration. We find that although family forest owners may not be particularly motivated to mitigate climate change, their forest management values and practices compliment many carbon-oriented management strategies. However, the strong value owners place on privacy and autonomy, and the weak importance many place on financial reward, may inhibit participation in policies and programs that incentivize carbonoriented management. These findings also have implications for policy efforts to encourage management for other ecological values besides carbon sequestration on family forestlands.
\end{abstract}

\section{Introduction}

Nonindustrial private or "family forestlands" (i.e., lands owned by individuals, couples, family estates, and other unincorporated groups but not tribes, or real estate, or investment firms) present an opportunity for contributing to climate change mitigation through increased carbon sequestration. These lands comprise $35 \%$ of all forestland and $58 \%$ of all productive timberland [1] in the United States. As such, they represent a significant portion of the land base where carbon can be sequestered through forestry. Despite this potential, family forestlands are not sequestering as much carbon as is biologically possible [2]. Moreover, development and other land uses are threatening to reduce the carbon sequestration potential of these lands. The area in nonindustrial private or family forestland in the U.S. has declined by almost 10\%, from 304 million acres in 1953 to 291 million acres in 2002 [1]. When forestland is lost to development, its carbon sequestration potential is also lost. The carbon sequestration potential of forestland is also limited by forest management practices, for example, harvesting on short rotation intervals.

The ecological literature identifies a number of forest management practices that could help sequester more carbon on forestlands, and the economics literature explores market and policy incentives that might affect management for increased carbon sequestration by family forest owners. However, little is known about other factors that may affect owners' willingness to manage for carbon and respond to policies designed to encourage carbon-oriented management. This paper addresses this knowledge gap by drawing on the published social science literature on family forest owners to identify social and cultural influences on their willingness to manage for carbon and respond to different policies that encourage carbon-oriented forest management on their lands.

We begin by discussing influences on family forest management-owners' values, ecological knowledge, and risk perceptions - and the extent to which they may affect management for carbon sequestration. We then compare 
family forest owners' management practices with the forest management practices identified in the scientific literature as being important for carbon sequestration. We also summarize owners' patterns of communication and learning, program participation and cooperation, and the types of policies that are popular and effective among them. Finally, we draw on these discussions to identify seven key summary points on how social and cultural characteristics may enable or constrain carbon sequestration on family forestlands and how policy may be able to address them.

\section{Influences on Forest Management}

2.1. Values. Although policy makers and assistance providers historically viewed family forest owners as small-scale versions of industrial forest owners who were driven to produce timber, it is now widely recognized that owners typically prioritize nonmarket values over timber production [35]. Enjoying beauty and scenery, protecting nature and biodiversity, passing land to heirs, and having privacy are top reasons for owning forestland for U.S. family forest owners [6].

Owners' values for beauty and scenery reflect their aesthetics and cultural heritage. For example, Erickson et al. [7] found that Midwestern owners' enjoyment of seasonal changes in their forests, and views of working landscapes, encourage them to manage for hardwoods, conifers, and meadows. Bliss [8] suggests that, depending on their ethnicity, owners in the Midwest may also manage for the orderliness of well-stocked plantations or the clean parklike structure of grazed, open woodlands. They may plant trees in open areas to convert fallow land into productive assets or let trees mature beyond their economic prime out of emotional attachment to the forest. In western Oregon, many owners associate forest stewardship with Douglas-fir forests, the symbol of that area's forest sector, although that aesthetic value is changing as owners become less dependent on timber markets and more aware and appreciative of other native ecotypes such as oak savanna and woodlands $[9,10]$. Perhaps because of these aesthetic values, many owners are conflicted about harvesting timber, especially using clearcutting, and converting forestland to other uses such as development $[6,11-13]$. Owners' values for scenery and beauty vary across regions. However, a common theme is that owners value mosaics of conifers, hardwoods, and meadows which typically contain lower actual and potential carbon storage than fully-stocked and highly productive conifer stands.

Owners' values for nature and biodiversity extend to a variety of ecosystem conditions and processes [13-15] such as species richness [10], historical conditions [9], riparian habitat and water quality $[16,17]$, rare species and wetlands $[15,18,19]$, game species [20], and in some cases, endangered species $[4,21]$. Perhaps as a result of these ecological values, many family forest owners favor diverse, less productive species, rather than or in addition to fast growing plantations, often at the expense of financial return
$[22,23]$. Also, given that family forest owners manage for a range of ecological values, it is possible that they may manage for global environmental conditions such as climate.

The importance of passing land on to heirs reflects the cultural and family legacy values that owners hold for their forestlands. Owners manage for landscapes that reflect the cultural heritage they would like to pass on [24] as well as the economic assets they would like their offspring to benefit from [25]. The value that owners place on the family legacy of forestland also reflects the time horizon owners manage on. Family forest owners typically consider future generations that may own their lands $[10,13,26,27]$. This time horizon lends itself to consideration of environmental problems that operate on large temporal scales such as climate change.

The value that owners place on privacy may influence the conditions of their forests as well as their patterns of social interaction. Many owners manage for fully-stocked forest stands that ensure the qualities of quiet and solitude for which they own forestland. In many cases these conditions are compatible with carbon sequestration, which generally increases with stocking. Also, for many owners, the need for privacy outweighs the benefits of coordinating management actions with neighbors or participating in public assistance and incentive programs $[18,28-30]$. Owners' values for privacy may be related to their fears about losing autonomy and being encumbered by environmental regulations and administrative burdens $[10,24,31]$. The desire for privacy and autonomy may discourage owners from participating in carbon-oriented assistance and incentive programs and market opportunities, as we will discuss later in this paper.

Despite family forest owners' focus on nonmarket values, the opportunity to derive income from the land is important for many owners [32]. Market prices for timber and wood products predict family forest management decisions according to some studies $[5,33]$. Indeed, most commercial timber on family forestlands is harvested [34], with the contribution of family forestlands to the U.S. timber harvest being greater than their proportional share of U.S. timberland area [6]. The opportunity to harvest timber is more important in the South [35] and the Pacific Northwest where the value of land for timber often exceeds the value of land for housing [36]. However, a meta-analysis of 34 studies [33] found that market prices are less likely to be significant determinants of management than government incentives and assistance programs: government incentive programs increase the likelihood of forestry activities such as treeplanting, harvesting, and reforestation [33, 37]. This may be because government policies and programs lower the cost of forest management (e.g., cost-share programs, technical assistance).

The investment value of land is also important for many owners. When values of land increase for residential uses, forests' amenity values also increase and the likelihood of harvesting and some other forms of management declines $[35,38]$. However, in regions with high income and population growth, where developed land values outweigh the financial and nonmonetary rewards owners receive from continued ownership of forest, demand for residential 
housing can result in conversion of forestland to housing [39].

Of course, great diversity exists among the ownership objectives of family forest owners [40], especially between regions. For example, owners in the North and West are more focused on aesthetic goals than owners in the South [35]. Absentee owners engage in fewer management activities [4143] including harvesting timber, managing for nontimber uses [26], and reducing wildfire risk [44]. Thus, forests on lands in absentee ownership may be left standing, a benefit for carbon sequestration, although they may not be managed actively to increase carbon sequestration potential. Owners with higher incomes, more education, and larger ownerships are more likely to engage in active management practices such as thinning and reforestation $[6,33,35,37,45]$ —but not harvesting $[37,41]$. Thus, forests in areas with more affluent and educated populations and larger ownerships are more likely to be managed for carbon sequestration.

A common thread in the literature on family forest owner values is that maintaining land in forest cover is important for aesthetic, ecological, family legacy, and privacy reasons. Nonetheless, owners will also be sensitive to market prices for timber, land, and carbon offsets even when they do not manage primarily for financial goals. Owners may be unlikely to pursue carbon-oriented management if it has a negative financial impact. Owners will also be sensitive to burdens on their privacy caused by participation in public programs and markets. Thus, carbon policies must help owners balance their values for ownership with external economic forces.

2.2. Ecological Knowledge. Although ecological values rank high among family forest owners, no research indicates that they have unusually high levels of knowledge about environmental issues in general or climate change in particular. A number of studies have shown that owners lack nuanced ecological knowledge. For example, they are not always well informed about the technical and scientific aspects of stream ecology, even when they are watershed council members [46, 47], or the biodiversity specific to the native ecotype of their lands [10]. Studies of knowledge and learning styles among family forest owners reveal a tension between scientific or expert knowledge and experiential or local knowledge. Owners tend to be independent and skeptical of experts [4850]. Although many owners think scientific research and expert information are necessary to improve their ability to manage their forests, some distrust scientific knowledge and view it as tentative and impractical $[10,24]$. While limited understandings of environmental concepts may not matter, in some cases they could cause owners to manage in ways that do not ultimately achieve their environmental goals [48-50].

There is a lack of published research that investigates family forest owners' understandings of how to manage forests for carbon sequestration. Some landowner organizations and extension offices sponsor workshops and develop materials to educate owners about how to manage for carbon, and forestry consultants also play an important role in this regard. However, it is likely that many owners have a limited understanding of how to manage forests to enhance carbon sequestration.

For example, a study by the authors of family forest owners in fire-prone areas in eastern Oregon (not yet published) revealed that some owners had assumptions about carbon sequestration and carbon-oriented forest management that are inconsistent with current scientific knowledge. Several owners interviewed believed that because young stands sequester carbon faster than older trees, mature marketable trees should be harvested, processed into long-lived wood products, and replanted. Owners also recommended harvesting stands of stressed, dead, dying, and burned trees because they no longer sequester carbon and either processing them into long-lived wood products or burning them for energy, and then replanting. These views contrast with the scientific literature in several ways. According to the scientific literature, the goal of carbonoriented management is to increase total carbon storage in forests, not the rate at which it is stored; older forests contain larger carbon stores than young forests $[51,52]$. Furthermore, when harvested trees are processed into wood products, 40 to 60 percent of the carbon they contain is released back to the atmosphere [53]. Moreover, most wood products have a shorter lifespan than trees. Forest carbon may also be lost in forest ecosystems when trees are harvested due to disturbance and decomposition [54]. Also, the carbon in standing and downed dead trees and snags can persist for a very long time; leaving dead biomass in the forest is one strategy for increasing carbon sequestration in forests because dead biomass is an important carbon pool. In the U.S., dead biomass on average accounts for $16 \%$ of all carbon stored in forest ecosystems [55].

Some of the owners the authors interviewed believed that fires in overstocked forests would exacerbate climate change by releasing carbon to the atmosphere. To avoid this risk, owners suggested thinning and processing smalldiameter trees. Several owners were emphatic about the need to develop markets for small-diameter logs and biomass to support these activities. Owners had varying perspectives on fire as a management tool in the era of climate change. Several expected drought conditions caused by climate change to make prescribed burning more hazardous; they suggested thinning instead to avoid unintentional releases of carbon through escaped fires. Others believed prescribed burning would release less carbon than the wildfires that would occur if forests were not treated. They also suggested using prescribed burning to enhance carbon sequestration in treated stands. The relationship between fire and carbon in forests is complicated. Although fuels reduction treatments can reduce the amount of carbon lost should a wildfire occur, treatments that occur in forests that do not subsequently burn cause real carbon losses. For example, the ability of prescribed burning to reduce the risk of carbon loss from wildfire is generally not enough to compensate for the amount of carbon emitted from repeated prescribed burns $[52,56]$. Alternatively, when small-diameter trees that cannot be used for long-lived wood products are thinned, carbon is lost to the atmosphere and this is generally not compensated 
for by an increase in carbon sequestration in the thinned forest.

The implication of these findings on family forest owners' ecological knowledge is that some owners are likely to be aware of climate change but they may not understand how different forest management options mitigate or exacerbate it. Without education about how carbon sequestration occurs in forest ecosystems, family forest owners may undertake management actions that reduce, rather than enhance, carbon sequestration in their forests.

2.3. Risk Perception. How owners perceive the risk of environmental changes affects their willingness to take action to mitigate these changes [57]. To date no published studies examine family forest owners' risk perceptions relating to climate change. However, existing research indicates that family forest owners' views on environmental issues are often similar to those of the general public $[11,40,58]$. According to a recent poll, $57 \%$ of American adults think climate change is happening but only $12 \%$ of American adults are very worried about global warming [59]. Few people view climate change as an immediate risk, and they tend to rank it as less important than many other social issues like the economy and terrorism [60]. We can infer from these findings that some family forest owners may be concerned about climate change, but few will rank it a top concern.

However, unlike the general public, owners of forestland are uniquely connected to the global carbon cycle: they may see the effects of climate change first hand in the conditions of their forests (drought stress, shifts in species composition toward drought tolerant species, increased stress-related mortality) and they are in a position to help mitigate climate change through carbon sequestration. Owners in eastern Oregon are concerned about climate changes as it relates to conditions on their properties, according to the unpublished study by the authors. Respondents to the authors' survey ranked climate change 10th out of 14 items they were concerned about contributing to fire risk on their properties. Fourteen percent of respondents were very concerned, $32 \%$ were moderately concerned, and $42 \%$ were not very concerned about climate change as a risk factor for fire. According to the authors' interviews, some owners believed drought conditions resulting from climate change will cause forest health problems and tree mortality, increasing hazardous fuels and making it harder to reestablish trees after fires or harvests.

A number of studies confirm that risk perception plays an important role in family forest owners' management decisions, particularly immediate biological, economic, and regulatory risks to their properties. In the South, perceived risks to trees, such as mortality from insects and diseases, and ice and wind damage, are important predictors of timber harvesting [38]. In the West, owners are more likely to mitigate fire risk when they are aware of the probability of fire, have direct experiences with fire, live on their forestland, and take a proactive role in forest management [61-65]. Those who perceive fire risk as controllable, catastrophic, or having fatal consequences and view their lands as vulnerable are also more likely to take management actions that mitigate this risk [63, 65]. However, owners will not always act to reduce risk, even when they feel threatened by it [66], perhaps because of other factors that constrain behavior such as the costs and benefits of taking action, and the economic, aesthetic, and ecological values owners see in their lands [63, 65]. Research from Sweden suggests that family forest owners act to address risks that threaten forest production when they have experienced them recently [67], and that owners are more concerned about economic risks (i.e., unfavorable market conditions) than biological risks [68] when making harvest decisions.

Another risk that concerns family forest owners is losing property rights and control over forest management decisions as a result of regulation [69-72]. A number of empirical studies suggest that these concerns influence management actions, in some cases triggering preemptive environmentally destructive practices by landowners [73], although there is also evidence that management practices are not affected (e.g., Johnson et al. 1997) [74].

An implication from the literature on risk perception is that owners will be more likely to take action if they are aware of and view themselves as being vulnerable to climate change, perceive high potential costs of climate change, and believe their individual actions can mitigate it. However, given that climate change occurs on a larger temporal and spatial scale than most landowners are used for dealing with and has complex and contested causes, anticipating impacts on the spatial and temporal scale of a typical forest property may be difficult. Policies designed to encourage family forest owners to manage for carbon may have to raise awareness about climate change risks as they relate to owners' properties.

\section{Forest Management Practices}

The forest management approaches family forest owners follow are heterogeneous, perhaps a reflection of their diverse values for owning forest land and the diverse regional contexts in which they manage [6]. Nevertheless, the literature suggests that many family forest owners already use, or are likely to use, forest management practices that promote carbon sequestration, especially in regions with long traditions of production-oriented management. At the same time, there is evidence that some carbon-oriented management practices may conflict with the approaches that more habitat-oriented owners prefer. Forest management practices known to sequester carbon can be categorized as follows: afforestation and reforestation to increase the stock of carbon-sequestering trees, avoided deforestation to prevent the release of carbon into the atmosphere and the loss of carbon sinks, and "improved" forest management to increase carbon sequestration in forest ecosystems [75, 76].

3.1. Afforestation/Reforestation. About one in five family forest owners plant trees on their land [6]. One reason few owners plant new trees is that they are reluctant to make large financial investments for long-term benefits [33, 7779]. Afforestation requires a substantial upfront investment 
of capital in site preparation and planting. Although the economics of afforestation are highly regional, even in the South where stumpage values are high, owners are only moderately likely to plant trees without public cost-share or other incentive programs [79]. In the South, tree planting is highly dependent on federal assistance programs and the availability of land that is not valuable for other uses, such as agriculture [80].

Owners may also be reluctant to plant trees for carbon sequestration because of their ecological and scenic values for diverse forest conditions. Some afforestation policies may encourage the planting of nonnative trees in plantations [81], which can lead to shifts in stand structure and species composition to more simplified, homogeneous conditions (i.e., plantations of fast growing species) [82-85]. This practice contrasts with the less intensive approach many family forest owners seem to prefer. For example, according to some studies owners cultivate slower growing, noncommercial timber species in addition to commercial species on their tree farms [10], and combine silviculture with grazing and agriculture [86]. Owners also set aside stands of hardwoods, brushy areas, and riparian corridors for habitat instead of converting them to plantations $[9,10,17]$. Some also use prescribed fire to reduce fuels, control invasive species, and mimic historical disturbance processes [87-89]. In some cases, family forests support more diverse species and structural conditions than other forest ownerships. In Oregon for example, diverse species and structural conditions are common on family forests, perhaps as a result of these practices [89]. Owners with strong ecological or aesthetic values who favor diverse forest conditions are unlikely to respond to afforestation and reforestation policies that encourage large upfront financial investments in the conversion of forested or unforested lands to nonnative species and plantations.

3.2. Avoided Deforestation. The practice of maintaining land in forest cover to avoid carbon loss is compatible with owners' amenity, ecological, and family legacy values and their reluctance to harvest timber and convert forestland to other uses. Many owners are also concerned about the conversion of forests to other uses such as development. However, owners' decisions to remove trees are often related to timber and land prices, which vary greatly across regions. As stated earlier, market prices do help explain harvesting and land conversion on family forestlands even though few owners claim financial return as a primary goal.

3.3. Improved Forest Management. Two "improved" forest management practices - extending harvest rotation intervals and reducing harvest related disturbance-may also be compatible with family forestry. Growing older and larger trees is consistent with owners' aesthetic, ecological and family legacy values, and ambivalence toward harvesting. Many owners manage their stands on longer rotations than their industrial counterparts. Even in regions such as the South and Pacific Northwest, where stumpage values are high, family forest owners harvest later than industrial owners, and many lament the pressure to reduce rotation lengths and stand diversity [90-92]. Conducting partial harvests to reduce harvest-related disturbance is consistent with family forest owners' preferences for nonclearcut methods of harvest. Half of all harvests on family forestlands are partial cuts or commercial thins while only $22 \%$ are clearcuts according to a pre-1993 study [93]. However, the cost and complexity of conducting partial harvests may present a challenge for some financially oriented owners. The practices of not burning slash and leaving biomass in the forest may also present a challenge for owners because they may conflict with owners' notions of order and aesthetics in forest landscapes [94].

\section{Communication, Program Participation, and Cooperation}

Owners' preferences for different types of communication and learning strategies, programs, and cooperation are important considerations in whether they are likely to engage in carbon-oriented forest management. Owners will need to follow several steps to be eligible for participating in carbon sequestration programs and markets, each having its own requirements for communication, learning, and cooperation. First, owners need to find out about programs that support managing forests for carbon, and markets for carbon sequestration. Then, to be eligible to participate they may be required to have a forest management plan or certification. They may also be required to conduct carbon inventories, which are complicated and often require special expertise, third-party verification, and monitoring [75]. These requirements may force owners to learn new techniques for forest planning, stand management, and inventory. As a result, owners often need to work with natural resource professionals, such as consulting foresters. Because most family forest owners' parcels are small, leveraging economies of scale is important for market entry. Entering into collective institutional arrangements and sharing the costs of inventories, verification and other fees and marketing can reduce the financial burden for individual landowners $[5,95]$. Entering into such arrangements may also reduce the uncertainty associated with hiring professional consultants, and strengthen ties and build networks among owners [96]. Examples of collective institutional arrangements include joining a carbon offset aggregation scheme [97], depositing the carbon sequestered by one's trees into a carbon bank where it can be loaned or rented [98] and joining an ecosystem services district that oversees the management of carbon within the district and facilitates member participation in carbon programs or markets [99]. In this section, we discuss social influences on how owners may proceed through these steps.

4.1. Communication and Learning. The literature provides some insight into owners' preferences for obtaining information and advice. According to a 2006 family forest owner survey, only $14 \%$ of owners have received advice about their forestland, representing $37 \%$ of the area in family ownership [6]. This advice comes primarily from 
state and federal agencies, private consultants, and other landowners. Interpersonal communication, on the other hand, especially between trusted peers has proved to be a very important channel of management advice for family forest owners, in part because of their tendencies to be independent and skeptical of expert knowledge. Traditional landowner assistance programs and organizations like the Extension Service and small woodland owner associations have responded to owners' ambivalence toward expert scientific knowledge and advice by fostering peer-to-peer exchanges of information through landowner-led tours and programs, in addition to traditional expert advice. Research suggests that the new wave of exurban forest owners are more likely to have environmental concerns and to distrust traditional sources of forestry information and advice [100]. These owners may seek out guidance from nongovernmental organizations such as watershed councils and private sector consultants more than family forest owners have in the past $[100,101]$. The literature on communication and learning among family forest owners suggests that technical assistance and education programs that rely on peer-based models of information sharing and education hold promise for encouraging carbon sequestration on family forestlands.

4.2. Program Participation. Statistics about family forest owner participation in formal programs and planning activities raise questions about the likelihood that they will respond to policies and programs encouraging carbonoriented forest management. According to the 2006 family forest owner survey, only 6 percent of owners have participated in a cost-share program (representing $21 \%$ of the forest area in family ownership) [6]. Only 4 percent of ownersrepresenting $17 \%$ of family forestland-have written a forest management plan [6], though many may have informal, unwritten plans for their forests. It is unknown how many owners have inventories of their forestlands, though the number is likely to be around $27 \%$, the proportion of owners who have conducted commercial harvests [6], because inventories are often conducted prior to harvesting [6].

Many carbon offset standards and programs require forest owners to have their forests certified as being sustainably managed by the Forest Stewardship Council, the Sustainable Forestry Initiative, or the American Tree Farm System [75]. Although 12\% of family forest owners have heard of sustainable forest certification, only one percent has had their forests certified. An additional two percent are considering certification [6]. Studies have suggested that owners are not willing to pay for certification and do not identify with its emphasis on forest management for eventual harvest $[102,103]$.

Owners' reluctance to participate in formal planning and programs may be attributable to their values for privacy and autonomy and skepticism about expert knowledge. However, studies also have identified demographic predictors of program participation that may be useful for policymakers. For example, owners who are more likely to participate are those with higher incomes [77], larger tracts [38], and more salient commercial interests. At the same time, owners who are more focused on timber income may require larger incentives [104] reflecting a sensitivity to opportunity costs. Further understanding of the factors that influence participation in forest management planning, programs, and certification schemes will be important for promoting carbon sequestration.

4.3. Cooperation. Understanding how and why owners cooperate with others is important for assessing the constraints and opportunities associated with their participation in collective institutional arrangements relating to carbon sequestration. To date, family forest owners have not exhibited tendencies toward collective action. Few prominent examples of cooperation exist in the U.S. among owners or between owners and other stakeholders $[105,106]$. The examples that do exist include cross-boundary cooperation by owners in clusters of 4 or 5 wooded parcels in New England [19], watershed councils in Oregon [106], and forest owner associations that provide forestry information and assistance in the Mid-West [100, 101]. Also, some organizations have attempted to aggregate owners to increase the economy of scale of carbon offset transactions (e.g., Woodlands Carbon in Oregon [97]).

The limited number of models for cooperation among family forest owners might be explained by their values for privacy and autonomy. Owners have a history of making decisions and managing and marketing their products independently $[100,107,108]$. Demographic characteristics may also be factors in owners' willingness to cooperate. Finley et al. [28] suggest that supporters of cooperation are younger, more highly educated, more affluent, and newer to forest ownership. Other elements that have been found to encourage cooperation are trust between owners and other stakeholders [31], a jointly perceived threat (e.g., development), and a common local geographic orientation [105], perhaps because it fosters a shared sense of place [109].

Although independent management may be more likely among family forest owners than coordination with others, some research suggests that owners may be willing to enter into cooperative arrangements if the risks and benefits are clear [16], examples of success are available [4], or economic incentives exist $[28,110]$. More research is needed on the conditions under which owners may be willing to cooperate with others to leverage benefits from planning and participating in public programs and markets on a larger economy of scale.

\section{Policy Tools for Encouraging Carbon-Oriented Forest Management}

Various policy tools have been considered for engaging family forest owners in carbon-oriented management. Despite the dozens of papers written on family forest owners and their practices, there is considerable uncertainty about the role of policy in influencing their behavior. Research on owners' responses to different policy tools has produced different and sometimes contradictory findings about which tools are most effective, perhaps reflecting the diversity of 
owners themselves and their circumstances. Fischer and Bliss [9] suggest that different suites of policy tools can have a place in family forestry, depending on the context and the values, constraints, and motivations of the owners. The success of any policy tool depends on the extent to which it encourages socially desirable behavior among members of the target group. One way to approach the development of policy tools is to reflect on what motivates a target group's behavior. Schneider and Ingram [111] provide a framework that categorizes policy tools by the assumptions about what motivates people to respond to them.

5.1. Authority Tools. Authority tools assume that people are motivated to obey laws and regulations and will act when they believe that existing law directs or permits them to [111]. It is generally assumed that collective goods (i.e., clean water, biodiversity, and sequestered carbon that are jointly consumed and nonexcludable) must be regulated by the public sector [112]. Indeed, rules and regulations (e.g., requirements for reforestation and riparian buffers in forestry) have played an important role in preventing the negative environmental externalities of natural resource use from leading to environmental damage [112]. However, rules and regulations may be insufficient for encouraging landowners to make positive contributions to the environment beyond what is necessary for preventing environmental degradation [92, 113, 114]. Owners' desire for autonomy and fear of losing control of their property can cause them to abhor many authority tools, in some cases countering the interest they would otherwise have in public policy goals [31, 69-73, 101, 115-117], although not all studies confirmed this trend (e.g., Johnson et al. 1997). Rules for replanting and management are being considered as part of climate change mitigation policy $[118,119]$. However, such rules should be approached with caution because they may have the effect of discouraging family forest owners from managing for carbon.

5.2. Incentive Tools. Incentive tools assume that individuals maximize utility and make choices that lead to tangible payoffs if they have adequate information, decision-making skill, and opportunity. Programs have offered incentives for stand improvement and environmental protection on family forestlands for decades through grants, cost-sharing, and favorable tax conditions [45]. For example, the Conservation Reserve, Forest Land Enhancement, and Environmental Quality Incentives Programs provide payments and costshare assistance to owners to remediate poor environmental conditions and reforest and improve stands [45]. In addition, federal tax reductions and state property tax deferral and credit programs have rewarded maintenance of forest cover and reforestation [45]. More recently, market-based incentives are being explored for encouraging the provision of ecosystem services on family forestlands. Carbon markets are perhaps the best developed ecosystem services markets that reward family forest owners for these services.

Evidence regarding the effectiveness of incentives in shaping family forestry practices has been mixed. Few owners participate in incentive programs $[41,117,120]$. As stated earlier, only $6 \%$ of family forest owners have participated in a cost-share program [6]. This rate is low considering that cost-share programs comprise the vast majority of incentives used by owners [121]. Owners generally do not manage differently in response to property tax and capital gains provisions [122-126]. Some studies have raised concerns about whether state property tax programs are even effective [127]. Several studies conclude that cost-sharing is the most efficient and effective incentive strategy [121]. Other studies conclude that owners will adopt some management practices regardless of assistance payments if these practices are consistent with the management objectives they have for their land $[104,126]$. A study in Texas found that range and forestland owners disapprove of publicly funded programs incentivizing afforestation for sequestering atmospheric carbon [128]. In general, incentives-when decoupled from technical assistance and one-on-one consultations with service foresters-have been of marginal benefit [123].

The limited appeal incentives have to owners may be due to the lack of importance owners place on financial reward as compared to other values such as privacy, and the risk they associate with entering into agreements with the government. Some studies suggest that the owners have not developed a culture of participation in incentives programs because programs have historically emphasized stand improvement over the habitat, scenic, and legacy values owners value more highly [41]. Owners who do participate in incentive programs are those who are motivated by family legacy and commercial or investment interests $[29,120]$.

Despite the poor track record of past incentive programs, according to the literature, new models for incentive programs may have potential. Langpap [129] suggests that compensation and regulatory assurances can have more significant effects on landowner management decisions than cost sharing. In a study of landowners in Oregon, Fischer and Bliss [24] suggest that market-based incentives may be more attractive than government programs to owners because they allow for more autonomy and flexibility. However, because carbon trading in the U.S. occurs largely in voluntary markets, prices for carbon offsets are too low for most owners $[75,85]$. A mandated cap and trade policy would likely change the economics of carbon offsetting by enforcing a carbon cap and raising the price of carbon offsets, although the acceptability of prices will still depend on the costs of management (e.g., tree planting, site preparation, inventories, verification, certification, and transaction fees) and forgone management and land use opportunities (e.g., shorter rotations, residential development, and agriculture) $[75,85,130,131]$. A pilot study in Massachusetts found that owners may be willing to sell carbon credits. Their willingness to sell increased with the length of commitment to the program required and decreased when there were penalties for early withdrawal from the program [131]. These findings suggest that while not all incentive programs will appeal to owners or entice changes in their behavior, incentive strategies may still have potential, especially if they address owners' concerns about the administrative encumbrances and risks of entering into legal agreements 
with government, and relinquishing control over forest management.

5.3. Capacity Tools. Capacity tools assume that people lack the necessary information, skills, or other resources to make decisions, but would welcome assistance if available. Technical assistance and education programs - both capacity tools_-are considered the most popular and efficient strategies for encouraging changes in forest landowner behavior $[121,123,124]$. For decades, the Extension Service and state forestry departments have provided technical assistance and education to landowners. Twice as many owners have received advice about their forestland than participated in cost-share programs [6]. Owners who have family legacy and investment and production motivations are particularly likely to support capacity building tools, compared to owners motivated by privacy, aesthetic, and residential goals [29]. Capacity tools do not address the financial challenges associated with carbon sequestration, but they do harness owners' existing motivations to manage for values such as carbon sequestration by giving them the tools to make appropriate management decisions.

5.4. Symbolic Tools. Symbolic tools assume that people are motivated by beliefs and values that are implicit in policy, and that their beliefs and values can be manipulated. Symbolic policy tools have addressed the stewardship beliefs and values of owners for decades. For example, programs like the American Tree Farm Association's Tree Farmer of the Year award and Forest Stewardship Council sustainable forestry certification symbolically reward owners for their forestry practices. Owners are clearly motivated by the values they associate with forest ownership, such as creating aesthetically appealing landscapes, passing on legacies, and providing habitat. However, few studies have examined the utility of symbolic policy tools for family forest owners. Symbolic tools, like capacity tools, cannot address the costs of committing to forest management practices that sequester more carbon. It is therefore unclear how well these programs can harness owners' beliefs and values about stewardship and environmental risk to change their behavior. If the future value society places on forests hinges on carbon sequestration, such tools will have more utility.

5.5. Learning Tools. Finally, learning tools assume that people are uncertain about the nature of a problem and its solution, but could adopt appropriate strategies as a result of learning and cooperative experiences. As stated previously, peer-to-peer and experiential learning are important for family forest owners. Learning tools go beyond capacity tools in that they involve stakeholders-both experts and lay people-working together to solve problems. Learning tools (i.e., community-based collaboratives) are gaining recognition in the field of natural resource management [132, 133]. Fischer and Bliss [24] suggest that initiatives in which owners work together and with natural resource professionals to address habitat degradation hold promise because they respect owners' preferences for devolved, negotiated decision-making and voluntary action. However, most examples of learning tools have been locally specific [134]. As a result, the utility of learning tools for addressing the global problem of climate change is unclear.

\section{Conclusions}

In this paper, we synthesized knowledge about social and cultural characteristics of family forest owners that may influence their willingness to manage for carbon and respond to different carbon-related policies. We find that family forest owners can potentially help mitigate climate change by doing more to manage for carbon sequestration. Not only do their lands comprise roughly one-third of all U.S. forestland, their forest management values generally compliment carbonoriented management. However, we find little evidence to suggest that owners are particularly motivated to alter their forest management to increase carbon sequestration for purposes of climate change mitigation. In addition, some carbon-oriented management practices such as afforestation may conflict with owners' values and practices. Furthermore, the strong value owners place on privacy and autonomy, and the weak importance many place on financial reward, may inhibit participation in some policies and programs that incentivize carbon-oriented management. Below we offer seven summary points on how social and cultural characteristics may enable or constrain carbon-oriented management by family forest owners and how policy can address them.

6.1. The Orientation of Family Forest Owners to Nonmarket Amenity and Ecological Values Indicates That They May Be Willing to Manage for Carbon Sequestration with Minimal Policy Intervention. Although there is no evidence that owners are particularly concerned about global climate change, owners' aesthetic, ecological, family legacy, and privacy values cause them to manage their land to maintain forest cover over time. If carbon sequestration were viewed as a benefit and moral obligation associated with ownership, owners might well manage for it with minimal policy intervention. Symbolic policies can promote carbon sequestration as part of stewardship by framing it in public discourse as an important ecosystem service that family forests provide, and recognizing individuals who manage to increase carbon sequestration on their lands.

\subsection{Family Forest Owners' Current Management Practices Are Largely Compatible with the Goal of Carbon Sequestration. Many family forest owners already have skills and resources to make forest management decisions and some of their practices are compatible with carbon sequestration. For example, owners are known to manage stands on long rotations and favor partial harvests. However, preliminary research suggests owners' ecological knowledge about forest management specifically to enhance carbon sequestration may be limited and misinformed. Some owners may need guidance in choosing specific forest management techniques that increase carbon sequestration on their properties and}


support the diverse species compositions and structural conditions that they value. Education and technical assistance will help owners increase their knowledge about how to manage for carbon and avoid practices that reduce carbon sequestration, such as burning slash in stands. Education and assistance can also help owners research markets for large diameter logs produced through longer rotations.

\subsection{Family Forest Owners' Preoccupation with Short-Term} Risks to Their Immediate Forest Holdings May Limit Their Attention to Long-Term, Large-Scale Risks Such As Global Climate Change. Like the general public, family forest owners may not be overwhelmingly concerned about climate change. Indeed, the nature of climate change itself works against risk perception; the causes and consequences of climate change are remote (not traceable to the region where an owner holds land, much less a specific parcel) and therefore may seem uncontrollable. People are more likely to take action if they are aware of and view themselves as being vulnerable to climate change, perceive great potential costs of climate change, and believe their individual actions can affect it (i.e., it is a controllable risk). Preliminary research suggests that owners are concerned about immediate biological risks to their forests such as fire, insects, and diseases, yet few published data exist regarding owners' concern about climate change. In fact, the management actions owners take to address more immediate risks such as fire may reduce rather than increase forest carbon sequestration (e.g., thinning, prescribed burns). Education can play an important role in raising awareness about climate change, translating its risks (e.g., increased rate and size of fires, droughts, or insect and disease outbreaks) to the scale of owners' parcels, and informing them about the unique position they are in to mitigate it.

6.4. Owners' Preferences for Diverse Forest Conditions May Limit Their Willingness to Adopt Some Carbon-Oriented Management Practices. Many family forest owners will be amenable to forest management practices that sequester carbon (e.g., managing on longer rotations and retaining more trees and vegetation after harvest) either because they already employ such practices or because such practices are compatible with their values. However, because of owners' aesthetic and ecological values, planting trees in open areas and replanting stands with plantations of nonnative species may be less palatable. The challenge for policy will be to harness owners' existing preferences for forestry practices to sequester carbon without conflicting with owners' other goals. Education and technical assistance on how to balance carbon sequestration with other goals will be important.

6.5. Owners' Values for Autonomy and Privacy May Limit Their Response to Some Programs and Policies. Family forest owners' concerns about losing control over their natural resource management decisions and having their privacy violated may limit their enthusiasm for formal management planning, cooperation with public agencies and other landowners, and participation in public programs. Owners who perceive a risk of being constrained by policy interventions will be less likely to respond to climate change mitigation policies than those who anticipate personal benefit, or feel that such policy goals are compatible with their own goals. Incentive tools have historically had limited appeal to owners, perhaps because they require legal contracts, whereas assistance programs, which impose fewer burdens on owners in exchange for information and advice, have been favored. Market-based incentives may appeal to owners because they can offer an alternative to government regulation. However, even market participation is not free of oversight; registering carbon offsets for market sale requires management plans, inventories, and in some cases, certification and easements. Furthermore, increasing the economy of scale to reduce per acre transaction costs requires aggregation of owners, thus entering into legal agreements. Incentive programs - both market and nonmarket-will be challenged to minimize or compensate for the administrative burden they impose on owners.

6.6. The Lack of Salience of Financial Reward among Owners' Motivations May Limit the Role of Financial Incentive Policies. The lack of overriding financial motivations for forest ownership compounded by concerns about the risks and burdens of entering into agreements with government agencies and other entities will likely limit owners' participation in financial incentive programs, unless the compensation is high enough and the required management practices compliment owners' other goals. For the subset of owners primarily motivated by tangible payoffs, and in cases where these financial motivations are not eclipsed by concerns about autonomy and flexibility, some form of public or market-based incentives may be appropriate. However, a combination of different types of policy tools will likely have the best outcome for encouraging carbon sequestration on family forest lands.

\subsection{Heterogeneity and Regional Differences among Owners} Limit the Utility of National Policy Strategies. The diversity in goals and management approaches of the nation's family forest owners makes it difficult to identify one type of policy to harness their motivations for carbon sequestration. Similarly, regional differences in forest conditions and economic contexts create different challenges and opportunities for owners in different areas. Owners who live in places where land values are low, forests are productive, and biological risks are small (e.g., western portions of the Pacific Northwest, some areas of the South) are more likely to be amenable to management for carbon sequestration. If no financial incentive programs exist, owners who manage for well-stocked stands of fast-growing conifer or hardwood species over long time horizons will be more likely to consider carbon sequestration as a goal. Owners who have higher incomes and educational attainment levels, own larger properties, and maintain their primary residences on their properties are most likely to be willing to manage their lands to enhance carbon sequestration. However, absentee owners who are 
not using their properties for residential purposes may be willing to leave their lands in forest cover, which is important from a carbon standpoint. If financial incentive programs do become more widely available, owners who prioritize financial goals may favor carbon-oriented management. In areas where high agricultural and residential values compete with forest land uses, or where forests are vulnerable to catastrophic threats such as fire, wind, or insect, and disease damage, owners may be more reluctant to commit to the long forest management horizons required for increasing carbon sequestration. A regional approach to developing policy strategies for carbon sequestration that addresses the motivations and constraints of different groups of owners in different areas will be important.

Just as family forest owners' motivations to manage for goals such as carbon sequestration are multifaceted, so must the strategies to address them be. Incentive tools clearly have a role in promoting carbon sequestration on family forestlands. Incentives can help entice owners to manage for goals that may not be intrinsically important to them and minimize the associated opportunity costs. Marketbased incentives may be especially appealing because they do not require owners to interact with government agencies. However, all types of incentives will face the same challenge: minimizing or compensating for the administrative burden imposed on owners. Without this, few owners will respond. Education and technical assistance will also be important, especially for raising awareness about the risks of climate change and the value of carbon sequestration among owners, and helping owners who are already inclined to manage for carbon develop appropriate practices that balance their multiple goals. Symbolic policies can help recognize owners who already manage successfully for carbon sequestration and encourage others to follow suit. Finally, the role of government should not be overlooked. Forestry activities that sequester carbon, and the supply and demand of carbon itself, will have impacts on the welfare of others. How forests are managed for carbon sequestration and how much land is placed into forestry for this purpose will also affect biodiversity and land prices, and what is produced on those lands (e.g., food, housing) [82]. Furthermore, the measurement and legal issues (i.e., property rights) associated with carbon offsets are complicated. For these reasons, some government regulation may be appropriate $[118,119,135]$.

Used alone, capacity building, symbolic, and authority tools will not be able to address the opportunity costs of new practices for carbon sequestration (e.g., extending rotations). Rather, a mixture of incentive and capacity-building tools will be important; for example, combining education and technical assistance with incentives. Approaching family forest owners with a portfolio of policies, and recognizing the contributions they already make to carbon sequestration will likely be most successful.

This literature synthesis has focused on the social and cultural influences that are likely to affect forest management for carbon sequestration on family forestlands. However, these same social and cultural influences will affect forest management by owners for other ecological values, such as habitat conservation and water quality, as well as their likelihood to respond to policies that promote these values. Thus, the findings are relevant for a broader range of natural resource issues than climate change.

\section{Acknowledgments}

The authors sincerely thank three anonymous reviewers and the following individuals for providing insightful review comments: J. Bliss, J. Kline, D. Diaz, and R. Alig.

\section{References}

[1] B. W. Smith, P. D. Miles, J. S. Vissage, and S. A. Pugh, Forest Resources of the United States, 2002, U.S. Department of Agriculture, Forest Service, North Central Research Station, St. Paul, Minn, USA, 2004.

[2] F. W. Cubbage, "Public and private forest policies to increase forest area and timber growth: programs, accomplishments and efficiency," in Forest Management Opportunities for Mitigating Carbon Emissions, R. N. Sampson and D. Hair, Eds., p. 379, American Forests, Washington, DC, USA, 1996.

[3] S. B. Jones, A. E. Luloff, and J. C. Finley, "Another look at family forests: facing our myths," Journal of Forestry, vol. 93, no. 9, pp. 41-44, 1995.

[4] M. W. Brunson, D. T. Yarrow, S. D. Roberts, D. C. Guynn Jr., and M. R. Kuhns, "Non-industrial private forest owners and ecosystem management-can they work together?" Journal of Forestry, vol. 94, no. 6, pp. 14-21, 1996.

[5] G. S. Amacher, M. C. Conway, and J. Sullivan, "Econometric analyses of nonindustrial forest landowners: is there anything left to study?" Journal of Forest Economics, vol. 9, no. 2, pp. 137-164, 2003.

[6] B. J. Butler, Family Forest Owners of the United States, 2006, U.S. Department of Agriculture, Forest Service, Northern Research Station, Newtown Square, Pa, USA, 2008.

[7] D. L. Erickson, R. L. Ryan, and R. De Young, "Woodlots in the rural landscape: landowner motivations and management attitudes in a Michigan (USA) case study," Landscape and Urban Planning, vol. 58, no. 2-4, pp. 101-112, 2002.

[8] J. C. Bliss, "Evidence of ethnicity: management styles of forest owners in Wisconsin," Forest and Conservation History, vol. 36, no. 2, pp. 53-72, 1992.

[9] A. P. Fischer and J. C. Bliss, "Behavioral assumptions of conservation policy: conserving oak habitat on family-forest land in the Willamette Valley, Oregon," Conservation Biology, vol. 22, no. 2, pp. 275-283, 2008.

[10] A. P. Fischer and J. C. Bliss, "Mental and biophysical terrains of biodiversity: conserving oak on family forests," Society and Natural Resources, vol. 19, no. 7, pp. 625-643, 2006.

[11] J. C. Bliss, S. K. Nepal, R. T. Brooks, and M. D. Larsen, "Environmental attitudes of mid-south forest owners," Southern Journal of Applied Forestry, vol. 21, no. 1, pp. 37-43, 1997.

[12] T. W. Birch, Private Forest Landowners of the United States, 1994, USDA Forest Service, NE Forest Experimental Station, Radnor, Pa, USA, 1996.

[13] M. G. Rickenbach, D. B. Kittredge, D. Dennis, and T. Stevens, "Ecosystem management: capturing the concept for woodland owners," Journal of Forestry, vol. 96, no. 4, pp. 1824, 1998.

[14] R. B. Hull, D. P. Robertson, and A. Kendra, "Public understandings of nature: a case study of local knowledge about 
"natural" forest conditions," Society and Natural Resources, vol. 14, no. 4, pp. 325-340, 2001.

[15] J. H. Creighton, D. M. Baumgartner, and K. A. Blatner, "Ecosystem management and nonindustrial private forest owners in Washington State, USA," Small-Scale Forest Economics, vol. 1, no. 1, pp. 55-69, 2002.

[16] M. G. Jacobson, "Factors affecting private forest landowner interest in ecosystem management: linking spatial and survey data," Environmental Management, vol. 30, no. 4, pp. 577583, 2002.

[17] D. D. Dutcher, J. C. Finley, A. E. Luloff, and J. Johnson, "Landowner perceptions of protecting and establishing riparian forests: a qualitative analysis," Society and Natural Resources, vol. 17, no. 4, pp. 319-332, 2004.

[18] D. L. Belin, D. B. Kittredge, T. H. Stevens, D. C. Dennis, C. M. Schweik, and B. J. Morzuch, "Assessing private forest owner attitudes toward ecosystem-based management," Journal of Forestry, vol. 103, no. 1, pp. 28-35, 2005.

[19] S. M. Campbell and D. B. Kittredge, "Ecosystem-based management on multiple NIPF ownerships," Journal of Forestry, vol. 94, no. 2, pp. 24-29, 1996.

[20] J. L. Haymond, "Wildlife attitudes of early adopters who own forestland," Society \& Natural Resources, vol. 3, no. 1, pp. 11$18,1990$.

[21] L. Raymond and A. Olive, "Landowner beliefs regarding biodiversity protection on private property: an indiana case study," Society and Natural Resources, vol. 21, no. 6, pp. 483497, 2008.

[22] R. Raunikar and J. Buongiorno, "Willingness to pay for forest amenities: the case of non-industrial owners in the south central United States," Ecological Economics, vol. 56, no. 1, pp. 132-143, 2006.

[23] A. L. Ross-Davis, R. Shorna, D. F. Jacobs, and A. S. Davis, "Afforestation motivations of private landowners: an examination of hardwood tree plantings in Indiana," Northern Journal of Applied Forestry, vol. 22, no. 3, pp. 149-153, 2005.

[24] A. P. Fischer and J. C. Bliss, "Framing conservation on private lands: conserving oak in Oregon's Willamette Valley," Society and Natural Resources, vol. 22, no. 10, pp. 884-900, 2009.

[25] I. Majumdar, D. Laband, L. Teeter, and B. Butler, "Motivations and land-use intentions of nonindustrial private forest landowners: comparing inheritors to noninheritors," Forest Science, vol. 55, no. 5, pp. 423-432, 2009.

[26] B. J. Butler, M. Tyrrell, G. Feinberg, S. VanManen, L. Wiseman, and S. Wallinger, "Understanding and reaching family forest owners: lessons from social marketing research," Journal of Forestry, vol. 105, no. 7, pp. 348-357, 2007.

[27] S. Rosenberg and R. D. Margerum, "Landowner motivations for watershed restoration: lessons from five watersheds," Journal of Environmental Planning and Management, vol. 51, no. 4, pp. 477-496, 2008.

[28] A. O. Finley, D. B. Kittredge, T. H. Stevens, C. M. Schweik, and D. C. Dennis, "Interest in cross-boundary cooperation: identification of distinct types of private forest owners," Forest Science, vol. 52, no. 1, pp. 10-22, 2006.

[29] J. J. Janota and S. R. Broussard, "Examining private forest policy preferences," Forest Policy and Economics, vol. 10, no. 3, pp. 89-97, 2008.

[30] A. O. Finley and D. B. Kittredge, "Thoreau, Muir, and Jane Doe: different types of private forest owners need different kinds of forest management," Northern Journal of Applied Forestry, vol. 23, no. 1, pp. 27-34, 2006.
[31] S. A. Bergmann and J. C. Bliss, "Foundations of crossboundary cooperation: resource management at the publicprivate interface," Society and Natural Resources, vol. 17, no. 5, pp. 377-393, 2004.

[32] R. L. Johnson, R. Alig, J. Kline, R. Moulton, and M. Rickenbach, "Management of non-industrial private forest lands: survey results from Western Oregon and Washington owners," in Research Contribution No. 28., p. 39, Oregon State University, Corvallis, Ore, USA, 1999.

[33] R. H. Beach, S. K. Pattanayak, J. C. Yang, B. C. Murray, and R. C. Abt, "Econometric studies of non-industrial private forest management: a review and synthesis," Forest Policy and Economics, vol. 7, no. 3, pp. 261-281, 2005.

[34] E. M. Carpenter, Ownership Change and Timber Supply, US Department of Agriculture Forest Service North Central Forest Experiment Station, St. Paul, Minn, USA, 1985.

[35] B. J. Butler, E. C. Leatherberry, C. Best, M. A. Kilgore, R. N. Sampson, and K. Larson, "America's family forest owners," Journal of Forestry, vol. 102, no. 7, pp. 4-9, 2004.

[36] J. D. Kline and R. J. Alig, "Forestland development and private forestry with examples from Oregon (USA)," Forest Policy and Economics, vol. 7, no. 5, pp. 709-720, 2005.

[37] R. J. Alig, K. J. Lee, and R. Moulton, Likelihood of Management on Nonindustrial Private Forests: Evidence from Research Studies, USDA Forest Service, Southeast Forest Experiment Station, Asheville, NC, USA, 1990.

[38] M. C. Conway, G. S. Amacher, J. Sullivan, and D. Wear, "Decisions nonindustrial forest landowners make: an empirical examination," Journal of Forest Economics, vol. 9, no. 3, pp. 181-203, 2003.

[39] J. D. Kline, R. J. Alig, and B. Garber-Yonts, "Forestland social values and open space preservation," Journal of Forestry, vol. 102, no. 8, pp. 39-45, 2004.

[40] L. Bourke and A. E. Luloff, "Attitudes toward the management of nonindustrial private forest land," Society and Natural Resources, vol. 7, no. 5, pp. 445-457, 1994.

[41] S. Joshi and K. G. Arano, "Determinants of private forest management decisions: a study on West Virginia NIPF landowners," Forest Policy and Economics, vol. 11, no. 2, pp. 132-139, 2009.

[42] J. Romm, R. Tuazon, and C. Washburn, "Relating forestry investment to the characteristics of nonindustrial private forestland owners in northern California," Forest Science, vol. 33, no. 1, pp. 197-209, 1987.

[43] M. Vokoun, G. S. Amacher, and D. N. Wear, "Scale of harvesting by non-industrial private forest landowners," Journal of Forest Economics, vol. 11, no. 4, pp. 223-244, 2006.

[44] A. P. Fischer, "Reducing hazardous fuels on nonindustrialprivate forests: factors influencing landowner decisions," Journal of Forestry. In press.

[45] N. R. Sampson and L. A. DeCoster, Public Programs for Private Forestry: A Reader on Programs and Options, American Forests, Washington, DC, USA, 1997.

[46] A. B. Hairston-Strang and P. W. Adams, "Oregon's streamside rules: achieving public goals on private land," Journal of Forestry, vol. 95, no. 7, pp. 14-18, 1997.

[47] A. S. Wright, Citizen Knowledge and Opinions about Watershed Management in the South Santiam Basin in Oregon, M.S. thesis, Department of Forest Resources, Oregon State University, Corvallis, Ore, USA, 2000.

[48] A. Brook, M. Zint, and R. De Young, 'Landowners' responses to an endangered species act listing and implications for encouraging conservation," Conservation Biology, vol. 17, no. 6, pp. 1638-1649, 2003. 
[49] E. Rogers, Diffusion of Innovations, Free Press, New York, NY, USA, 1983.

[50] P. C. West, J. M. Fly, and D. J. Blahna, "The communication and diffusion of NIPF management strategies," Northern Journal of Applied Forestry, vol. 5, no. 4, pp. 265-270, 1988.

[51] M. E. Harmon, W. K. Ferrell, and J. F. Franklin, "Effects on carbon storage of conversion of old-growth forests to young forests," Science, vol. 247, no. 4943, pp. 699-702, 1990.

[52] D. Diaz, S. Charnley, and H. Gosnell, "Engaging western landowners in climate change mitigation: a guide to carbonoriented forest and range management and carbon market opportunities," in General Technical Report PNW-GTR-801, United States Department of Agriculture, Forest Service, Pacific Northwest Research Station, Portland, Ore, USA, 2009.

[53] M. E. Harmon, S. L. Garman, and W. K. Ferrell, "Modeling historical patterns of tree utilization in the pacific northwest: carbon sequestration implications," Ecological Applications, vol. 6, no. 2, pp. 641-652, 1996.

[54] E. Sonne, "Greenhouse gas emissions from forestry operations: a life cycle assessment," Journal of Environmental Quality, vol. 35, no. 4, pp. 1439-1450, 2006.

[55] D. P. Turner, G. J. Koerper, M. E. Harmon, and J. J. Lee, "A carbon budget for forests of the conterminous United States," Ecological Applications, vol. 5, no. 2, pp. 421-436, 1995.

[56] M. Hurteau and M. North, "Fuel treatment effects on treebased forest carbon storage and emissions under modeled wildfire scenarios," Frontiers in Ecology and the Environment, vol. 7, no. 8, pp. 409-414, 2009.

[57] R. E. O'Connor, R. J. Bord, and A. Fisher, "Risk perceptions, general environmental beliefs, and willingness to address climate change," Risk Analysis, vol. 19, no. 3, pp. 461-471, 1999.

[58] J. C. Bliss, S. K. Nepal, R. T. Brooks, and M. D. Larsen, "Forestry community of granfalloon?" Journal of Forestry, vol. 92, no. 9, pp. 6-10, 1994.

[59] A. Leiserowitz, E. Maibach, and C. Roser-Renouf, "Climate change in the American Mind: Americans' global warming beliefs and attitudes in January 2010," in Yale Project on Climate Change, Yale University and George Mason University, New Haven, Conn, USA, 2010.

[60] American Psychological Association, "Psychology and Global Climate Change: Addressing a Multi-Faceted Phenomenon and Set of Challenges," American Psychological Association, Task Force on the Interface Between Psychology and Global Climate Change, 2009.

[61] A. Jarrett, J. Gan, C. Johnson, and I. A. Munn, "Landowner awareness and adoption of wildfire programs in the southern United States," Journal of Forestry, vol. 107, no. 3, pp. 113$118,2009$.

[62] G. S. Amacher, A. S. Malik, and R. G. Haight, "Nonindustrial private landowners, fires, and the wildland-urban interface," Forest Policy and Economics, vol. 7, no. 5, pp. 796-805, 2005.

[63] S. McCaffrey, "Thinking of wildfire as a natural hazard," Society and Natural Resources, vol. 17, no. 6, pp. 509-516, 2004.

[64] J. S. Fried, G. J. Winter, and J. K. Gilless, "Assessing the benefits of reducing fire risk in the Wildland-Urban interface: a contingent valuation approach," International Journal of Wildland Fire, vol. 9, no. 1, pp. 9-20, 1999.

[65] G. Winter and J. S. Fried, "Homeowner perspectives on fire hazard, responsibility, and management strategies at the wildland-urban interface," Society and Natural Resources, vol. 13, no. 1, pp. 33-49, 2000.
[66] S. McCaffrey, "Understanding public perspectives of wildfire risk," in Wildfire Risk, Human Perceptions and Management Implications, W. E. Martin, C. Raish, and B. Kent, Eds., pp. 11-22, Resources for the Future, Washington, DC, USA, 2008.

[67] K. Blennow and O. Sallnäs, "Risk perception among nonindustrial private forest owners," Scandinavian Journal of Forest Research, vol. 17, no. 5, pp. 472-479, 2002.

[68] L. Lönnstedt and J. Svensson, "Non-industrial private forest owners' risk preferences," Scandinavian Journal of Forest Research, vol. 15, no. 6, pp. 651-660, 2000.

[69] P. V. Ellefson, "Has Gifford Pinchot's regulatory vision been realized?” Journal of Forestry, vol. 98, no. 5, pp. 15-22, 2000.

[70] R. Innes, "The economics of takings and compensation when land and its public use value are in private hands," Land Economics, vol. 76, no. 2, pp. 195-212, 2000.

[71] S. Polasky and H. Doremus, "When the truth hurts: endangered species policy on private land with imperfect information," Journal of Environmental Economics and Management, vol. 35, no. 1, pp. 22-47, 1998.

[72] A. H. Raedeke, J. S. Rikoon, and C. H. Nilon, "Ecosystem management and landowner concern about regulations: a case study in the Missouri Ozarks," Society and Natural Resources, vol. 14, no. 9, pp. 741-759, 2001.

[73] D. Lueck and J. A. Michael, "Preemptive habitat destruction under the endangered species act," Journal of Law and Economics, vol. 46, no. 1, pp. 27-60, 2003.

[74] R. L. Johnson, R. J. Alig, E. Moore, and R. J. Moulton, "NIPF landowners' view of regulation," Journal of Forestry, vol. 95, no. 1, pp. 23-28, 1997.

[75] L. A. Wayburn, J. F. Franklin, and J. C. Gordon, Forest Carbon in the United States: Opportunities and Options for Private Lands, The Pacific Forest Trust, San Francisco, Calif, USA, 2007.

[76] R. W. Malmsheimer, P. Heffernan, S. Brink et al., "Forest management solutions for mitigating climate change in the United States," Journal of Forestry, vol. 106, no. 3, pp. 115171, 2008.

[77] G. S. Amacher, M. C. Conway, and J. Sullivan, "Nonindustrial forest landowner research: a synthesis and new directions," in Southern Forest Science: Past, Present, and Future, H. M. Rauscher and K. Johnsen, Eds., pp. 241-252, U.S. Department of Agriculture, Forest Service, Southern Research Station, Ashville, NC, USA, 2004.

[78] K. G. Arano and I. A. Munn, "Evaluating forest management intensity: a comparison among major forest landowner types," Forest Policy and Economics, vol. 9, no. 3, pp. 237-248, 2006.

[79] J. D. Kline, B. J. Butler, and R. J. Alig, "Tree planting in the south: what does the future hold?" Southern Journal of Applied Forestry, vol. 26, no. 2, pp. 99-107, 2002.

[80] R. Nagubadi and D. Zhang, "Determinants of timberland use by ownership and forest type in Alabama and Georgia," Journal of Agricultural and Applied Economics, vol. 37, no. 1, pp. 173-186, 2005.

[81] S. Matthews, R. O’Connor, and A. J. Plantinga, "Quantifying the impacts on biodiversity of policies for carbon sequestration in forests," Ecological Economics, vol. 40, no. 1, pp. 71-87, 2002.

[82] R. Alig, D. Adams, B. McCarl, J. M. Callaway, and S. Winnett, "Assessing effects of mitigation strategies for global climate change with an intertemporal model of the U.S. forest and agriculture sectors," Environmental and Resource Economics, vol. 9, no. 3, pp. 259-274, 1997. 
[83] C. Hoover and S. Stout, "The carbon consequences of thinning techniques: stand structure makes a difference," Journal of Forestry, vol. 105, no. 5, pp. 266-270, 2007.

[84] A. Caparrós and F. Jacquemont, "Conflicts between biodiversity and carbon sequestration programs: economic and legal implications," Ecological Economics, vol. 46, no. 1, pp. 143$157,2003$.

[85] E. H. Im, D. M. Adams, and G. S. Latta, "Potential impacts of carbon taxes on carbon flux in western Oregon private forests," Forest Policy and Economics, vol. 9, no. 8, pp. 10061017, 2007.

[86] J. H. Lawrence, L. H. Hardesty, R. C. Chapman, and S. J. Gill, "Agroforestry practices of non-industrial private forest landowners in Washington State," Agroforestry Systems, vol. 19, no. 1, pp. 37-55, 1992.

[87] A. P. Fischer, Listening to Landowners: Conservation Case Studies from Oregon's Willamette Valley, Defenders of Wildlife, West Linn, Ore, USA, 2005.

[88] D. I. McConnell and S. B. Baldwin, "Private, non-industrial forest owner's perceptions of controlled burning influencing forest management," in Proceedings of an International Symposium on Fire and the Environment, Ecological and Cultural Perspectives, S. C. Nodvin, Ed., USDA Forest Service, Southeastern Forest Experiment Station, Knoxville, Tenn, 1991.

[89] B. J. Stanfield, J. C. Bliss, and T. A. Spies, "Land ownership and landscape structure: a spatial analysis of sixty-six Oregon (USA) Coast Range watersheds," Landscape Ecology, vol. 17, no. 8, pp. 685-697, 2002.

[90] J. C. Bliss and E. C. Kelly, "Comparative advantages of smallscale forestry among emerging forest tenures," Small-Scale Forestry, vol. 7, no. 1, pp. 95-104, 2008.

[91] S. K. Pattanayak, B. C. Murray, and R. C. Abt, "How joint is joint forest production? An econometric analysis of timber supply conditional on endogenous amenity values," Forest Science, vol. 48, no. 3, pp. 479-491, 2002.

[92] C. Best and L. A. Wayburn, America's Private Forests: Status and Stewardship, Island Press, Covelo, Calif, USA, 2001.

[93] M. Bennett, Timber harvesting and marketing practices on NIPF lands in western Oregon, M.S. thesis, Forest Management, Oregon State University, Corvallis, Ore, USA, 1993.

[94] P. H. Gobster, "An ecological aesthetic for forest landscape management," Landscape Journal, vol. 18, no. 1, pp. 54-64, 1999.

[95] F. W. Cubbage, Economics of Tract Size: Theory and Literature, USDA Forest Service, 1983.

[96] R. J. Gass, M. Rickenbach, L. A. Schulte, and K. Zeuli, "Crossboundary coordination on forested landscapes: investigating alternatives for implementation," Environmental Management, vol. 43, no. 1, pp. 107-117, 2009.

[97] Woodlands Carbon, 2010, http://www.woodlandscarbon .com/.

[98] H. Bigsby, "Carbon banking: creating flexibility for forest owners," Forest Ecology and Management, vol. 257, no. 1, pp. 378-383, 2009.

[99] R. L. Goldman, B. H. Thompson, and G. C. Daily, "Institutional incentives for managing the landscape: inducing cooperation for the production of ecosystem services," Ecological Economics, vol. 64, no. 2, pp. 333-343, 2007.

[100] M. Rickenbach, K. Zeuli, and E. Sturgess-Cleek, "Despite failure: the emergence of "new" forest owners in private forest policy in Wisconsin, USA," Scandinavian Journal of Forest Research, vol. 20, no. 6, pp. 503-513, 2005.
[101] M. G. Rickenbach, J. C. Bliss, and A. S. Reed, "Collaboratives, cooperation, and private forest ownership: implications for voluntary protection of biological diversity," Small-Scale Forest Economics, Management, and Policy, vol. 3, no. 1, pp. 69-83, 2004.

[102] M. G. Rickenbach, "Forest certification of small ownerships: some practical challenges," Journal of Forestry, vol. 100, no. 6, pp. 43-47, 2002.

[103] J. E. Leahy, M. A. Kilgore, C. M. Hibbard, and J. S. Donnay, "Family forest landowners' interest in and perceptions of forest certification: focus group findings from Minnesota," Northern Journal of Applied Forestry, vol. 25, no. 2, pp. 73$81,2008$.

[104] J. D. Kline, R. J. Alig, and R. L. Johnson, "Forest owner incentives to protect riparian habitat," Ecological Economics, vol. 33, no. 1, pp. 29-43, 2000.

[105] D. B. Kittredge, "The cooperation of private forest owners on scales larger than one individual property: international examples and potential application in the United States," Forest Policy and Economics, vol. 7, no. 4, pp. 671-688, 2005.

[106] M. G. Rickenbach and A. S. Reed, "Cross-boundary cooperation in a watershed context: the sentiments of private forest landowners," Environmental Management, vol. 30, no. 4, pp. 584-594, 2002.

[107] V. A. Sample, "Building partnerships for ecosystem management on mixed ownership landscapes," Journal of Forestry, vol. 92, no. 8, pp. 41-44, 1994.

[108] M. G. Jacobson, R. C. Abt, and D. R. Carter, "Attitudes toward joint forest planning among private landowners," Journal of Sustainable Forestry, vol. 11, no. 3, pp. 95-112, 2000.

[109] T. S. Cheng, Place' as a Mediating Variable in Natural Resource Politics and Collaboration: An Annotated Bibliography, Department of Forest Resources, Oregon State University, Corvallis, Ore, USA, 1998.

[110] R. Klosowski, T. Stevens, D. Kittredge, and D. Dennis, "Economic incentives for coordinated management of forest land: a case study of southern New England," Forest Policy and Economics, vol. 2, no. 1, pp. 29-38, 2001.

[111] A. Schneider and H. Ingram, "Behavioral assumptions of policy tools," Journal of Politics, vol. 52, no. 2, pp. 510-529, 1990.

[112] F. Cubbage, P. Harou, and E. Sills, "Policy instruments to enhance multi-functional forest management," Forest Policy and Economics, vol. 9, no. 7, pp. 833-851, 2007.

[113] P. V. Ellefson, M. A. Kilgore, and J. E. Granskog, "Government regulation of forestry practices on private forest land in the United States: an assessment of state government responsibilities and program performance," Forest Policy and Economics, vol. 9, no. 6, pp. 620-632, 2007.

[114] C. S. Holling and G. K. Meffe, "Command and control and the pathology of natural resource management," Conservation Biology, vol. 10, no. 2, pp. 328-337, 1996.

[115] C. Cocklin, N. Mautner, and J. Dibden, "Public policy, private landholders: perspectives on policy mechanisms for sustainable land management," Journal of Environmental Management, vol. 85, no. 4, pp. 986-998, 2007.

[116] R. L. Johnson, R. J. Alig, E. Moore, and R. J. Moulton, "NIPF landowners' view of regulation," Journal of Forestry, vol. 95, no. 1, pp. 23-28, 1997.

[117] D. Zhang and W. A. Flick, "Sticks, carrots, and reforestations investment," Land Economics, vol. 77, no. 3, pp. 453-456, 2001. 
[118] S. A. Kennett, "National policies for biosphere greenhouse gas management: issues and opportunities," Environmental Management, vol. 30, no. 5, pp. 595-608, 2002.

[119] K. Richards, "Coercion and enterprise in the provision of environmental public goods: the case of carbon sequestration in the United States," Critical Reviews in Environmental Science and Technology, vol. 27, pp. S293-S307, 1997.

[120] V. Nagubadi, K. T. McNamara, W. L. Hoover, J. Walter, and L. Mills, "Program participation behavior of nonindustrial forest landowners: a probit analysis," Journal of Agricultural and Applied Economics, vol. 28, no. 2, pp. 323-336, 1996.

[121] M. A. Kilgore and C. R. Blinn, "Policy tools to encourage the application of sustainable timber harvesting practices in the United States and Canada," Forest Policy and Economics, vol. 6, no. 2, pp. 111-127, 2004.

[122] J. Greene, S. Daniels, M. Jacobson, M. Kilgore, and T. Straka, Existing and Potential Incentives for Practicing Sustainable Forestry on Non-industrial Private Forest Lands, National Council for Science and the Environment, Washington, DC, USA, 2005.

[123] M. A. Kilgore, J. L. Greene, M. G. Jacobson, T. J. Straka, and S. E. Daniels, "The influence of financial incentive programs in promoting sustainable forestry on the nation's family forests," Journal of Forestry, vol. 105, no. 4, pp. 184-191, 2007.

[124] M. G. Jacobson, T. J. Straka, J. L. Greene, M. A. Kilgore, and S. E. Daniels, "Financial incentive programs' influence in promoting sustainable forestry in the Northern Region," Northern Journal of Applied Forestry, vol. 26, no. 2, pp. 61-67, 2009.

[125] M. G. Jacobson, J. L. Greene, T. J. Straka, S. E. Daniels, and M. A. Kilgore, "Influence and effectiveness of financial incentive programs in promoting sustainable forestry in the south," Southern Journal of Applied Forestry, vol. 33, no. 1, pp. 3541, 2009.

[126] R. A. Kluender, T. L. Walkingstick, and J. C. Pickett, "The use of forestry incentives by nonindustrial forest landowner groups: is it time for a reassessment of where we spend our tax dollars?" Natural Resources Journal, vol. 39, no. 4, pp. 799$818,1999$.

[127] C. M. Hibbard, M. A. Kilgore, and P. V. Ellefson, "Property taxation of private forests in the United States: a national review," Journal of Forestry, vol. 101, no. 3, pp. 44-49, 2003.

[128] K. L. Olenick, U. P. Kreuter, and J. R. Conner, "Texas landowner perceptions regarding ecosystem services and cost-sharing land management programs," Ecological Economics, vol. 53, no. 2, pp. 247-260, 2005.

[129] C. Langpap, "Conservation of endangered species: can incentives work for private landowners?" Ecological Economics, vol. 57, no. 4, pp. 558-572, 2006.

[130] C. H. Huang and G. D. Kronrad, "The cost of sequestering carbon on private forest lands," Forest Policy and Economics, vol. 2, no. 2, pp. 133-142, 2001.

[131] L. S. Fletcher, D. Kittredge, and T. Stevens, "Forest landowners' willingness to sell carbon credits: a pilot study," Northern Journal of Applied Forestry, vol. 26, no. 1, pp. 35-37, 2009.

[132] J. M. Wondolleck and S. L. Yaffee, Making Collaboration Work: Lessons from Innovation in Natural Resource Management, Island Press, Washington, DC, USA, 2000.

[133] S. L. Yaffee and J. M. Wondolleck, "Making collaboration work," Conservation Biology in Practice, vol. 1, no. 1, pp. 17$25,2000$.

[134] A. S. Cheng, Who's in place, who's out of place: examining the politics of natural resource collaboration, Ph.D. thesis, Forest
Resources, Oregon State University, Corvallis, Ore, USA, 1999.

[135] K. R. Richards, R. Alig, J. D. Kinsman, M. Palo, and B. Sohngen, "Consideration of country and forestry/land-use characteristics in choosing forestry instruments to achieve climate mitigation goals," Critical Reviews in Environmental Science and Technology, vol. 27, supplement 1, pp. S47-S64, 1997. 

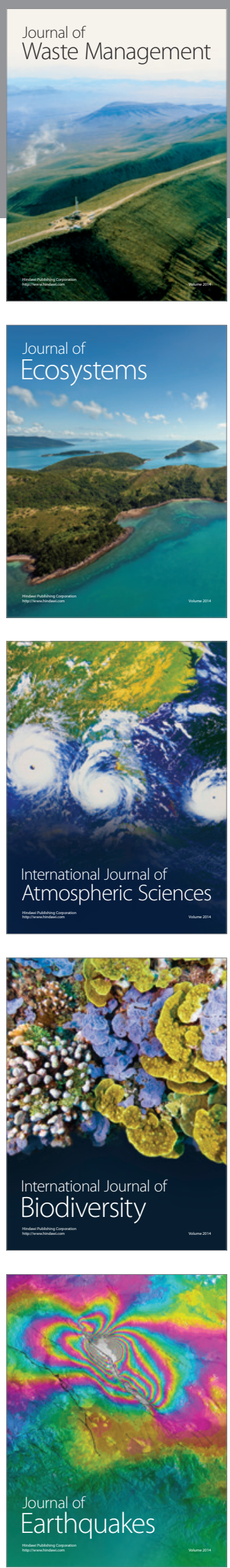
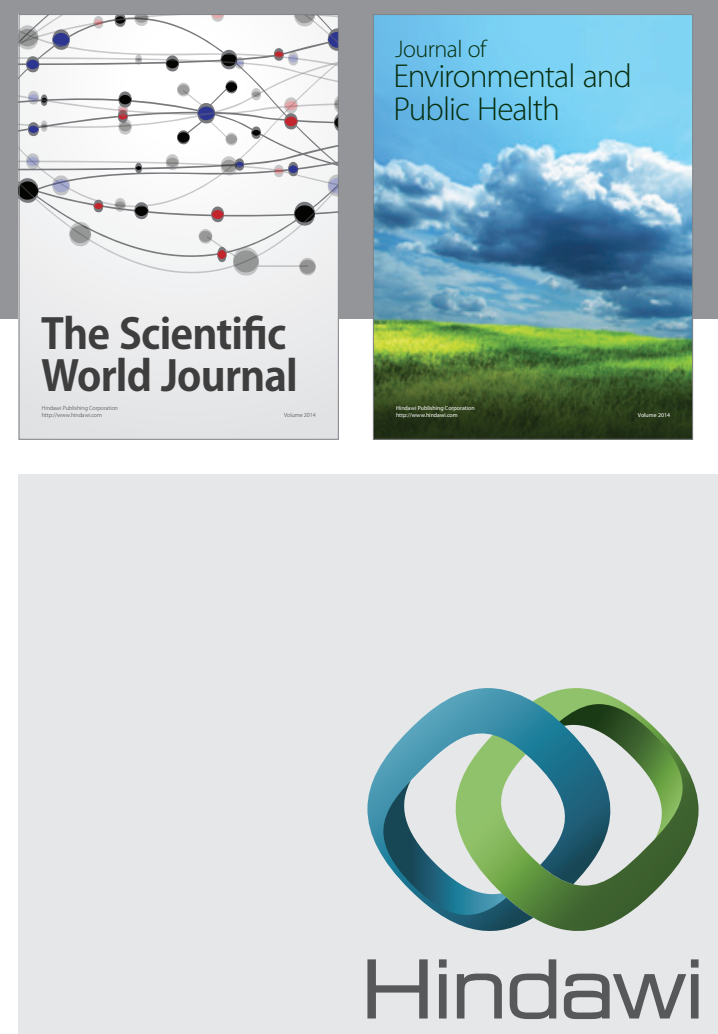

Submit your manuscripts at

http://www.hindawi.com
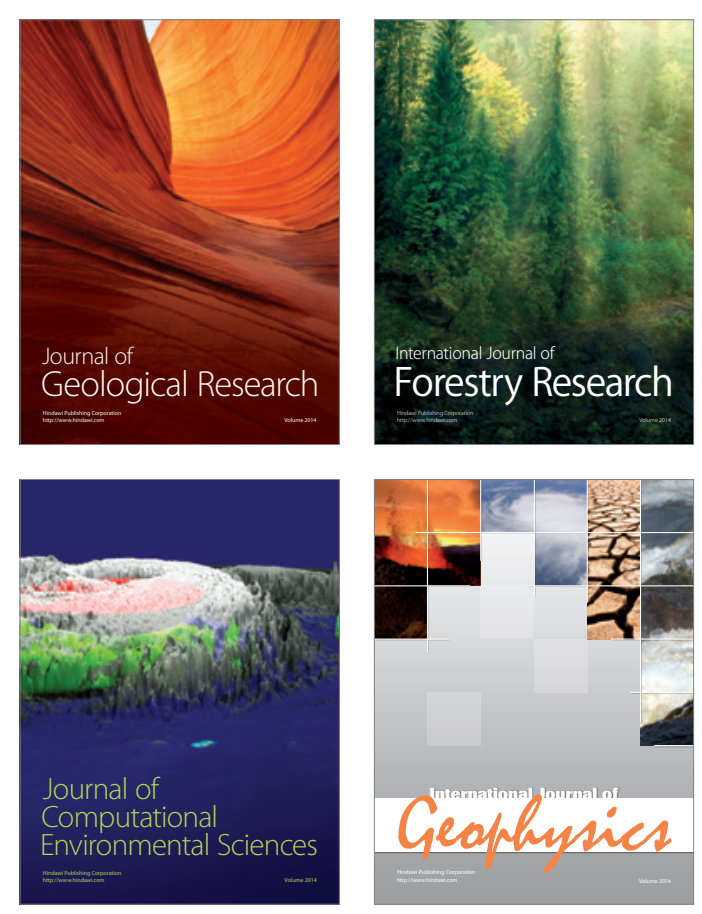
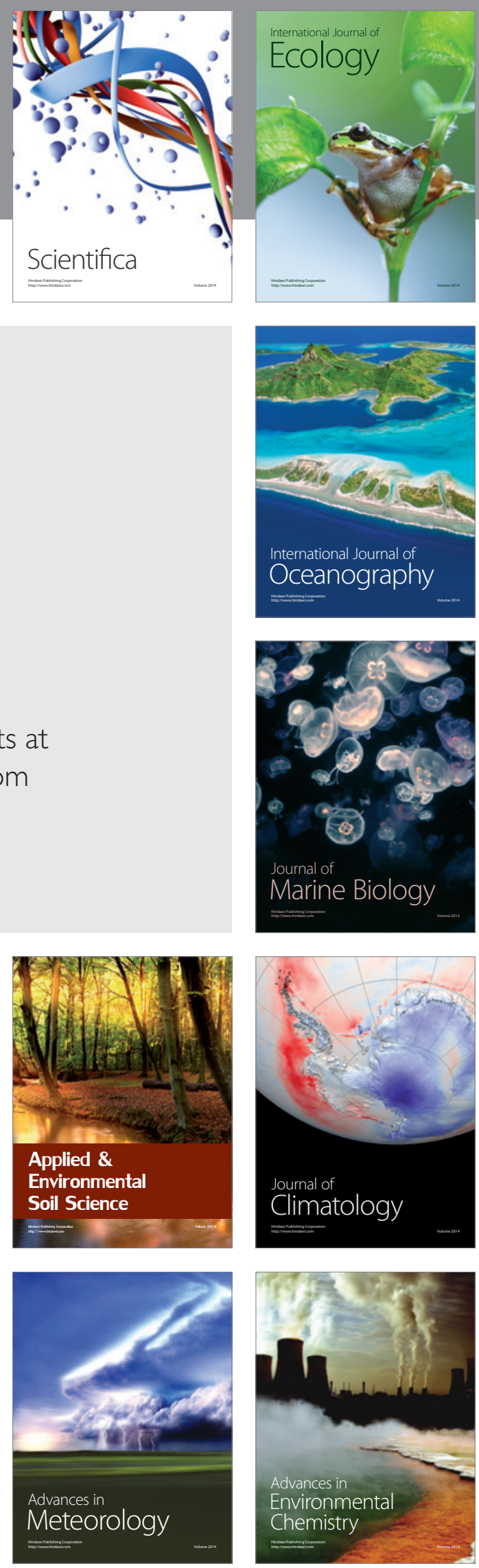